\title{
Implementing the proposed outer ring road in Kathmandu Valley
}

Bijaya K Shrestha

Urban Designer, Email: bibiyan_shrestha@yahoo.co.uk.

Accepted 25 June 2013

The proposed 72 kilo meter long Outer Ring Road (ORR) project for the Kathmandu valley constitutes the construction of $\mathbf{5 0}$ meter wide road (eight lane highway) and development of 250 meter of land on either side through land pooling technique. It has a vision of developing the valley as a 'national capital region' and managing the population growth in the next 15-20 years through planned urban development. This ambitious project covers forty village development committees, three municipalities and one metropolitan city. Numerous stated objectives of the proposed ORR project such as decentralisation of commercial and office activities to the peripheral new areas through development of new 'business centres' with mixed land use and coordinated infrastructure development at different nodal points are difficult to achieve in the present situation. The reasons are due to inadequate legal and institutional framework, poor capacity of the implementing agency, lack of master plan of the Kathmandu valley and absence of planning standards and urban design guidelines at city level. The overall results are formation of urban sprawl of residential use in the peripheral areas with traffic congestion in the existing urban centres and historic cores, acute shortage of drinking water, electricity and other basic amenities and destruction of traditional settlement in the rural areas including intensification of earthquake vulnerability. However, this mega project can be successfully implemented after improving in the existing legal and institutional framework, coordinating with the public utility providing agencies and promoting urban design approach including formulation of urban design guidelines with incentives in the form of tax cut and floor area bonus.

Key words: Outer ring road, land polling, legal and institutional framework, design guidelines

\section{Overview}

The combination of 'pull factors' in urban areas - expansion of industrial, business and service activities, and the 'push factors' in the rural areas - low socio-economic development, natural disaster causing loss of lives and properties, the recent past political disturbance including adaptation of centralised policy by the past successive government have attracted huge population 
migration into the Kathmandu valley for better income opportunity, education, health, safety and other services (Shrestha, 2013; Basnet, 2011; Sakai, et al. 2001; Adhikari \& Bohle, 1999; Ertur, 1994). The valley comprising of five municipalities and additional ninety seven villages accommodates about 2.51 million populations with average annual growth rate of $4.3 \%$ between 2001 and 2011(Muzzini \& Aparicio, 2013). This population accounts 42 percent of the total urban population of Nepal against the corresponding distribution of 39 percent in 2001. Kathmandu, the capital of Nepal is also administrative, cultural, economic and tourist centre of Nepal houses population of approximately 1.06 million over an area of 899 square kilometres (Central Bureau of Statistics, 2012).

This growth of population and expansion of urban area is causing huge pressure on the existing infrastructure as well as demand of new public services in the peripheral urban sprawl (Choe \& Pradhan, 2010; Nepal Development Forum, 2002). To respond it, the government of Nepal implemented site and services, guided land development and land pooling programmes ${ }^{1}$ during the 1970s and 1980s. Moreover, it has also enacted various acts (Town Development Act 1998, Municipality Act 1992, Joint Apartment Act 1997, Local Self Governance Act 1999) and established different ministries related to urban development (Ministry of Housing and Physical Planning in 1988, Ministry of Population and Environment in 1995 and Ministry of Urban Development in 2012). ${ }^{2}$ In continuation to these efforts, the government of Nepal in the fiscal year 2004-'05 decided to launch the Outer Ring Road (ORR) project. ${ }^{3}$ Earlier two studies on transportation carried out by Nepal Engineering Consultancy Services Centre Limited (NEPECON) in 2000 and the Japan International Cooperation Agency (JICA) in 1993 identified the need of better transportation network by linking route like Lubhu (Lalitpur) to Gokarna (Kathmandu). As the social and environmental impact study of the proposed ORR is underway, people are divided regarding the pros and cons of this ambitious project. Some have strongly advocated the immediate implementation of this project whereas others have cautioned the negative impacts of it. Land brokers see this scheme as an opportunity for their investments; villagers residing in different locations hope to get benefits from the construction of the road; again others are lobbying to bring the road alignment near to their settlements (Pant, 2005). Against such background, this paper aims to make critical review of the proposed ORR project focusing on the implementation aspect with

\footnotetext{
${ }^{1}$ The government in 1977 started site and services programmme for housing development in Kuleswore, Dallu and Golfutar areas, opened the road in the existing area (guided land development) about 305 kilo meter and land pooling projects in many parts of the Kathmandu Valley. In the site and service programme, the original landowners get little compensation and often displaced whereas landowners get serviced plots in the land pooling project. Hence, among the three types, the latter is the most popular.

${ }^{2}$ In fact, there are various layers of public agencies for the planned development of the Kathmandu valley: many ministries, National Planning Commission, Kathmandu Valley Development Authority, municipalities and Village Development Committees

${ }^{3}$ In fact, this ambitious project was initiated without supporting feasibility studies.
} 
fourfold objective. First, it elaborates the major components of the proposed ORR project. Second, it analyses the existing legal and institutional framework of urban development by reviewing the past implemented and ongoing projects in the Kathmandu valley. Third, it presents consequences of executing the ORR project in the present state. Fourth, it proposes some basic pre-requisite conditions for successful implementation before drawing a conclusion.

\section{Major components of the proposed outer ring road}

The proposed ORR project comprises of two major components:- construction of the main road having 50 meter of Right of Way (ROW) and development of 250 meter of land on either side of the road through land pooling, altogether the development of 550 meter belt of land (Department of Urban Development \& Building Construction, 2008). According to the government of Nepal, this ambitious project is necessary not only to contain the population growth in the next 15-20 years but also to create a new bypass for Kathmandu metropolitan area (ibid). Moreover, it aims to delineate rural urban boundary and to create integrated infrastructure development corridor - water, electricity, telephone, sewerage, and so on (ibid). The proposed alignment of the road is based on the 'rural urban boundary' of Kathmandu Valley Plan 2020 (Kathmandu Valley Town Development Committee, 2000) and recommendations suggested by JICA (JICA, 1993) and NEPECON in the feasibility study of 2000. Considerations of geology, topography and drainage patterns of the land were considered in road alignment, avoiding the fertile agriculture land, environmentally sensitive areas (such as dense forest and protected areas) and security zones. The ORR will connect numerous isolated nodal points of the three principal cities of the Kathmandu Valley (Fig 1). The alignment will merge in the existing Ring Road (constructed 30 years ago) from 'Sitapaila to Balaju Bypass' and the existing portion of 'Araniko' Highway from 'Jagati to Thimi.' Also proposed is to join 'Banepa-Bardibas' Highway and 'Kathmandu-Hetauda' Expressway and 'Tribhuvan' Highway (DUDBC, 2008).

The proposed ORR will have separate lanes for vehicles and low speed bicycle in the same road section. Two vehicular lanes will be designed for desirable speed of 60-80 kmph whereas the service lanes will have speed designed for 30-50 kmph in both directions. In addition to these, there will be provision of off street parking. Such road with provisions of highway, service road, bicycle lanes, parking space including greenery belt and pedestrian path will be the first of this type in Nepal (Fig 2).

For the planning purpose, the land on both side of the ORR is conceptually categorised into three different 'sectors' (Kathmandu, Lalitpur and Bhaktapur) at district level (WELINK Consultants, 2005). They are further scaled down into 'sub-sectors' with many neighbourhoods. Each neighbourhood measuring $1.6 \mathrm{~km}$ long and $543 \mathrm{~m}$ wide is composed of six 'blocks' (one block comprising of more than 15 clusters) of different size, three on either side of the road (Fig 3). 
Separated by $8 \mathrm{~m}$ wide road, the central block having area of 335 ropani ( 1 ropani $=508.74 \mathrm{sqm}$ ) will have bigger space compared to the side blocks of 210 ropani land.

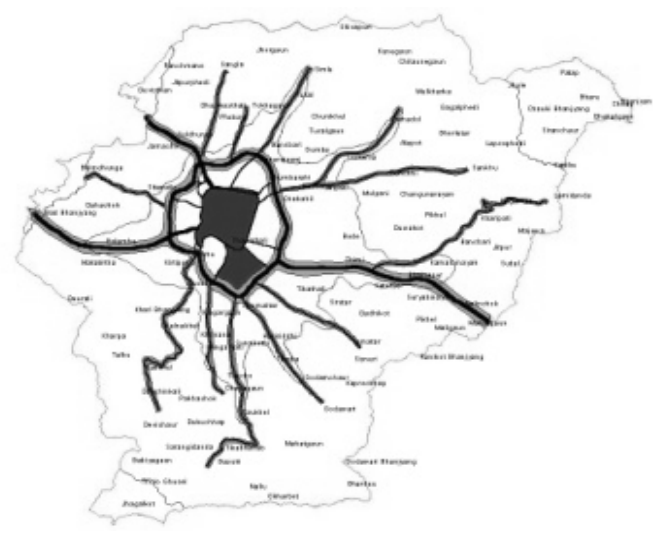

(a) Existing road patterns

Fig. 1. Proposed Outer Ring Road linking different nodal points of the Kathmandu Valley (Source: DUDBC, 2008)



Fig. 2. Typical road section detailing of the ORR project (Source: DUDBC, 2008) 


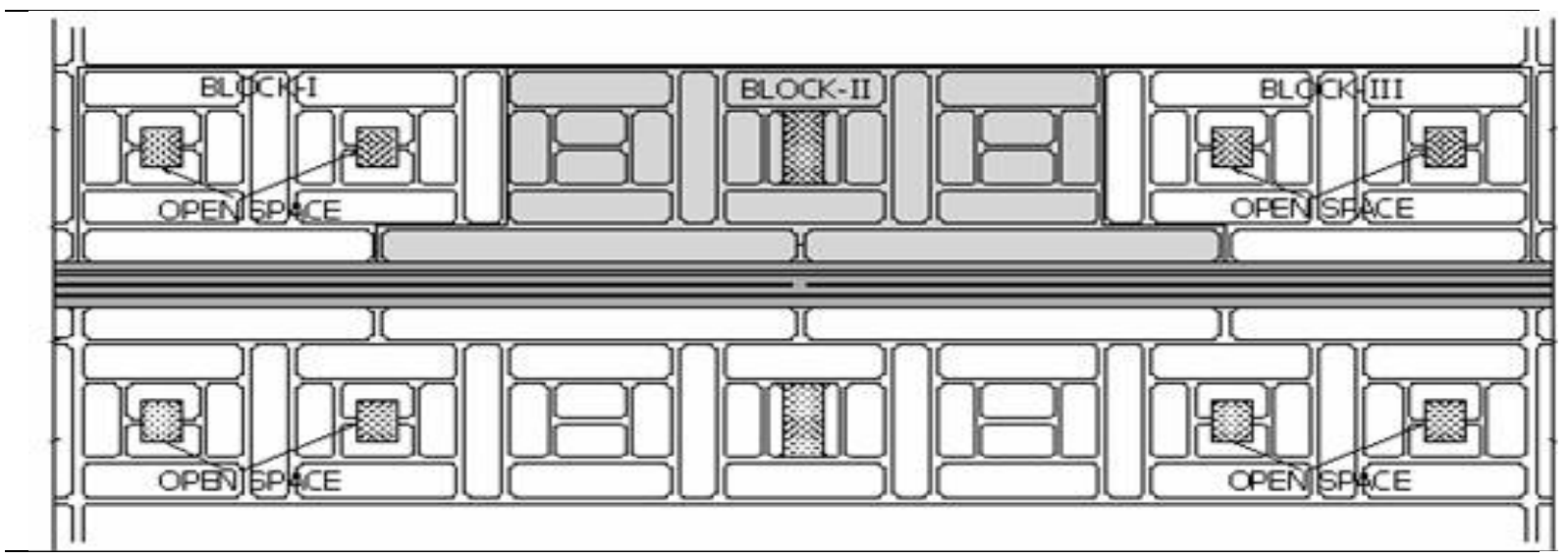

Fig. 3. Conceptual layout of neighbourhood and block in the proposed Outer Ring Road project (Source: WELINK Consultants, 2005)

According to the government, integration of rural settlements to urban centres and linkages between the southern and eastern parts of the valley will be better through ORR construction. Land needed for numerous public utilities and services such as administrative sub-centres, commercial sub-centres, and intercity bus terminus in the capital metropolitan city will be made available through planned extension of the present settlements towards the ORR. This road is expected to become the backbone of urban growth in future. Though financial assistance from the government of China is expected for the construction of major highway, the government of Nepal is responsible for providing land for the road and other feasibility studies. The Department of Urban Development and Building Construction (DUDBC) under the Ministry of Physical Planning and Works (now under the Ministry of Urban Development) has qualified numerous private consulting firms to carry out different parts and aspects of the road and urban development. So far, studies of intersection of the proposed ORR, improvement of radial road including impacts of ORR on traditional settlements and development of conceptual townscape and land readjustment model have been completed. The land required for the proposed road having 'right of way' $50 \mathrm{~m}$ is estimated to be about 360 ha (7,200 ropani approximately), which costs approximately NRs 5 billions. ${ }^{4}$ Compulsion land acquisition is irrelevant not only because of the huge land cost but also due to bitter experience (court hearing, time consuming, conflict with local land owners and so on) in similar cases in the past. Hence, the government has decided to acquire the land for road construction through land pooling technique.

\footnotetext{
${ }^{4}$ This project cost is based on cost calculated at the time of project initiation. However, the present cost will be much higher than this one.
} 
Implementing the proposed outer ring road in Kathmandu Valley

\section{Shortcomings in the existing legal and institutional framework}

The shortcomings in the existing legal and institutional framework of urban growth management of the Kathmandu valley are basically threefold. First, there is a lack of legal and institutional mechanism to translate the broad objectives set at central level into project specific for implementation at local level. Co-ordination among different agencies working particularly at city level is also inadequate. Kathmandu Valley Development Plan 2020 has clearly set the objective of promoting traditional cities of the valley as cultural hubs. Similarly, the National Shelter Policy 1996 and recently updated National Housing Policy 2011 (2068 BS) has emphasised the housing need of urban poor and their easy access on finance. However, Kathmandu Valley Development Authority (earlier Kathmandu Valley Town Development Committees) and local municipalities including government departments are yet to come up with necessary policies, programmes and projects to realise those broad objectives.

Urbanisation policy at national level is missing. Carrying capacity of the Kathmandu valley is unknown. Officially approved master plan is not available for the Kathmandu valley. The earlier five master plans proposed in 1963, 1969, 1976, 1984 and 1991 for the planned development of the valley were never implemented. All planned housing development and land pooling projects implemented by the public agency have been carried out in isolation without linking to the whole city context (Shrestha, 2006a). In such planned areas, timely provision of water supply, electricity, telephone cables and other amenities have not been carried out due to lack of participation and coordination among the district level line agencies. Many local real estate companies neither register their company with the government nor do they get approval of their land development schemes from the Town Development Agency.

Second, there are no planning standards and urban design ${ }^{5}$ guidelines to regulate large scale new development and redevelopment works. Street network, open spaces and layout plan has different provisions in terms of quantity and quality in the planned residential development (Shrestha, 2005). The gross density in these planned areas is also low (e.g, 159 person per hectare at 'Kuleswore housing project' and 143 person per hectare at 'Gongabu land pooling project') compared to the recommended minimum gross density of 300 person per hectare in the proposed Development Plan 2020 of the Kathmandu Valley. Despite having comparable project area in 'Liwali' and 'Sinamangal' land pooling projects, open space allocation varies: 2.8 percent in 'Liwali' and 5.3 percent in 'Sinamangal' (Shrestha, 2006a). Unscientific street layout, lack of open space and social amenities and poor orientation of the street blocks are the main features in many land pooling projects implemented by private sectors. Real estate companies and individuals involved in real estate sector are successful in making huge profit margin, giving burden to the

\footnotetext{
${ }^{5}$ Though planning and design of cities (and part of it) are carried out by urban designer at present in many parts of the world, the word 'urban design' is new for Nepal and it does not exist in the contemporary planning and development works here in Nepal.
} 
government side for provision of infrastructure and emergency services in those developed areas. The formed built environment is sterile and mono-functional with many individual good buildings which do not fit into the surrounding landscape.

The existing building bylaws based on the land use map of 1976 is the only legal tool for urban growth management. As it is applicable only for new construction, it cannot address the activities like vertical division and haphazard renovation of traditional building stocks in the historic core areas, occupancy (building use) change in the buildings (conversion of residential houses into school, nursing home, etc.) and so on. Such activities are responsible for increasing seismic vulnerability. Moreover, permission from the education authority (and health authority) is enough to run the private schools (or nursing homes) irrespective of the seismic specification of the buildings and other safety measures. The building bylaws aim to control the individual building based on site coverage, floor area ratio, building height and setback including right of way. However, it does not consider the urban form, built environment and public realm. As a result, it has failed to deliver a desirable urban growth (Shrestha Joshi, 2007). Outdated government regulations on land and housing together with rapid urban population growth have inflated housing prices, which are beyond the capacity of urban poor (Maskey, 2007). In many cases, the bylaws are conflicting with the existing other legislations. For instance, the 'Ancient Monument Preservation Act 1956` empowers the Chief District Officer after getting request from Department of Archaeology, to give order for the destruction of the houses or part of it that are constructed against the prevailing law whereas the 'Local Self-Governance Act-1999' gives power to the Mayor to punish defaulter either by imposing fine (upto NRs. 100,000) or by demolishing the building or part of it. The city cannot take any action unless it is informed by the affected party. Similarly, the Traffic Transport Management Act 1992 empowers Department of Transport Management to mange transport and traffic including controls of vehicular emission and condition and road accident (MoLJ, 1992) whereas the Local Self Governance Act 1999 strengthens local government's role in planning and development works with little power on urban road sector (MoLJ, 1999).

Third, the public agencies are simply ineffective even in enforcing simple clauses of the byelaws such as building height restriction, floor projection, ground coverage or set back requirement through building permit system and construction monitoring. Lack of coordination and cooperation among the three interrelated agencies namely local government for issuing building permit), KVDA, earlier KVTDC for monitoring the construction site) and Chief District Office for punishing defaulters is clearly visible. Any semi-skill person (not architect or building engineer) who has obtained diploma on civil engineering or architecture is qualified for design and supervision of building construction (less than three storeys and of $1000 \mathrm{sq}$. $\mathrm{ft}$ ground coverage). Once the building permit is received from the city office, the owner himself with the help of local masons erects the building on the site. Construction detailing and other changes are carried out based on masons' past experience and owner's requirement. It is believed that as high as 90 percent 
of private construction in Kathmandu and Lalitpur are non-engineered and unmonitored and illegal home construction is as high as 27 percent (CBS, 1997).

The combined effects of these shortcomings have resulted poor performance even in government participated projects. For instance, in redevelopment of 'Dharahara - Sundhara Public Plaza' (Shrestha \& Shrestha, 2006) and 'Construction of Overhead Pedestrian Bridges' (Shrestha, 2006b), the private sector was successful to use public spaces for commercial activities in different ways. At Dharahara-Sundhara case, construction of shops has reduced the public space whereas construction of Greenery Park with restaurant in the public space has given access to only those who can pay entry fee. Earlier there was free access to all on this public plaza. People's sentimental attachment with the public space was not considered, while converting such public spaces into commercial uses. Other local government involved projects include the conversion of different types of cultural spaces of Kathmandu - 'Te-Bahal' (one of the biggest Buddhist Monasteries of Kathmandu), 'Bhugol Park' (Earthquake Memorial Park) and 'Tundikhel' (the biggest open space of Kathmandu) into the parking spaces for short-term economic benefit. In addition to these, the increasing urban sprawl in the peripheral areas, haphazard building transformation in the urban centres, huge housing deficits (Shrestha, 2010), inadequate public amenities and growing number of slums and squatter settlements (Shrestha, 2013) together with the growing environmental pollution and its negative impact on public health (Ghimire, 2008) best illustrate the limitation of the existing legal and institutional framework.

\section{Consequences of ORR}

While implementing the proposed ORR project under the existing legal and institutional framework it will create a new set of urban problems. The reasons are numerous. First, the proposed new development (both planned in the prescribed area and unplanned in the surrounding areas) will attract more people from the surrounding districts into the Kathmandu valley for better employment opportunity, education, health services and other facilities. It is not clear, how and where to engage those new migrants. The valley does not have any new business activity or new set up of industry that requires huge population. Those migrants can also not be easily accommodated in the land pooled areas due to private land ownership. Ultimately, most of them will end up in slums and squatter settlements either along the riverbanks or in the public lands. Lack of job and income generating activity will increase crime and vandalism in the cities. Those influx populations will have to share the existing inadequate amenities such as drinking water, electricity and so on thereby aggravating the present state of crisis. The limited natural resources and carrying capacity of the valley cannot simply afford the present trend of urban growth, which does not allow the integration of economic development and environmental sustainability. 
Second, construction of $50 \mathrm{~m}$ wide arterial road together with urban development of $250 \mathrm{~m}$ on each side of the road will convert approximately 3,961 ha of land into the built spaces in the Kathmandu valley. Moreover, the trickle-down effect of such development will go beyond the planned areas thereby causing further reduction in farmlands, forests, wetlands and open spaces. Land fragmentation and its conversion into built form will not only deteriorate natural environment, affecting the habitat of many species but also reduce the agricultural product in the peripheral areas. Continuing the present trend of urbanisation even without ORR project will convert all agricultural land of the valley except in the hill (15\%) into haphazard growth area by 2020 (Table 1) (MoPE, 1999). Open space and recreation area is gradually decreasing in Kathmandu and Lalitpur: from 255 ha. (4.1\%) in 1971 to 245 ha. (3.9\%) in 1981 and further to 143 ha. (2.2\%) in 1991(Halcrow Fox Associates et. al, 1991). The per capita total open space in Kathmandu is about 4.6 sq. m. and the per capita organised open space is much lower at $0.97 \mathrm{sq} . \mathrm{m}$. (Maneesh, 2003) whereas the total garden parks cover an area of $3.06 \mathrm{sq}$. km. only.

Table 1: Reduction of agricultural land and intensification of urban growth in the Kathmandu valley

\begin{tabular}{lcccccc}
\hline & $\mathbf{1 9 8 4}$ & $\mathbf{1 9 9 1} * \boldsymbol{1 9 9 4}$ & $\mathbf{2 0 0 0} *$ & $\mathbf{2 0 1 0}^{*}$ & $\mathbf{2 0 2 0}$ \\
\hline $\begin{array}{l}\text { Urban Area (\% of total } \\
\text { Valley area) }\end{array}$ & 4.8 & 11.0 & 13.1 & 18.0 & 26.0 & 34.3 \\
& & & & & & \\
\hline $\begin{array}{l}\text { Agricultural Area (\% } \\
\text { of total Valley area) }\end{array}$ & 64.0 & 56.0 & 49.6 & 42.2 & 28.3 & 14.5 \\
\hline
\end{tabular}

Note: ** Projected by Halcrow Fox, * projected by linear regression analysis Source: (MoPE, 1999)

Third, the ribbon type development of $250 \mathrm{~m}$ land on either sides of the 8 lanes arterial road to be implemented through the existing practice of land pooling technique will result on the formation of low density private housing. Planned development is possible only on the 60 percent of the length of the road due to topographical situation of the valley. Huge chunk of land on the right of way of the roads in the remaining length of the road (40\%) needs to be either compensated based on the market rate or to be adjusted in the land pooled areas. It requires extra contribution from the land owners. As the development cost has to be cash out from the local landowners only by selling extra plots, it will also face similar problems of little contribution for open space, road network and other socio-cultural and emergency amenities by landowners. The government can neither impose the land use regulation in the land pooled areas nor can control the conversion of residential houses into schools, health centre or other public oriented uses under the existing legal framework. As a 
result, these new development will be converted into dormitory section of the Kathmandu valley with little social benefit for the public at large. The only beneficiaries will be the local landowners, whose land values increase by many folds. In such case, the objectives of ORR to plan as new business centre with commercial, social and recreational facilities in the land pooled area cannot be achieved. Despite close proximity from the urban centre, many nodal points in the existing Ring Road could not function as a new business centre. Same fate will be there in the new road junction (which is far away from the urban centres) of the proposed ORR. As the land contribution from the private landowners will be consumed in the arterial road construction, the government does not has any legal tool and mechanism at present to develop commercial and other activities in the private lands.

Fourth, development of residential neighbourhood adjacent to such arterial road is not suitable due to many reasons. Proposed conceptual layout of the neighbourhood community on the limited width of land in the same fashion - one open space at the centre, straight roads dividing the urban fabrics in opposite orientation and high rise structure along the arterial road - will form monotonous urban environment (Photo 1). The transverse vehicular and pedestrian network among different blocks of the same neighbourhood is weak due to arterial road in between. The inhabitants living on both sides will feel physically, visually and psychologically separated from the same community. As in the past cases, the issues of urban form, spatial connection with the surrounding areas, energy conservation, children's safety and peaceful environment, socialization opportunity and sense of community formation, all required for a good residential quarter is hardly acknowledged in the conceptual layout plan.



(a) ORR separating the same neighbourhoods

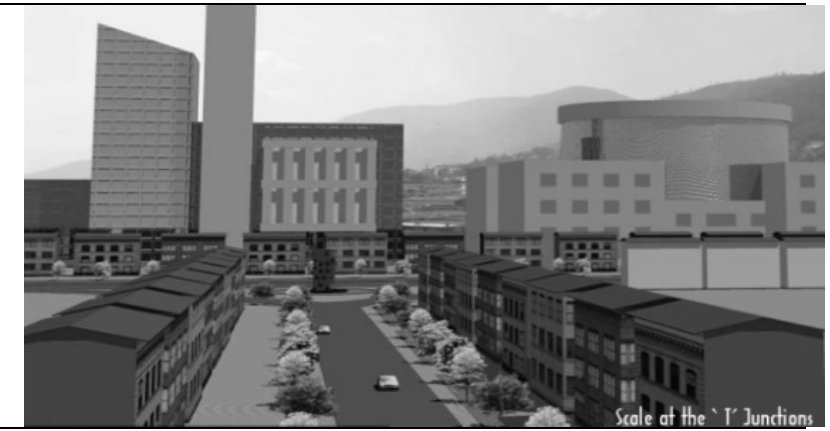

(b) Residential neighbourhood and high rise construction (T junction)

Photo 1. Monotonous neighbourhood due to constrains of arterial road and land width

The conceptual design of different road junctions and the proposed land use for a typical neighbourhood area clearly indicates the continuation of the past trend of developing residential 
plot only (Table 2). Instead of proposing mixed land use for creation of lively and diverse environment, land use segregation is proposed. Proposing vehicular roads on both sides of the river, for instance at 'Chovar - Satungal' area (Manandhar, 2008) means failure to acknowledge the significance of water-body and lost opportunity of creating diverse public amenities along the water's edge. Creation of multi-storey structures for vehicular parking is not desirable in such planned areas.

Table 2: Proposed land use allocation for a typical neighbourhood in the land pooled area

\begin{tabular}{|c|c|c|c|c|c|c|c|}
\hline \multicolumn{4}{|c|}{$\begin{array}{c}\text { Proposed land use of a typical } \\
\text { neighbourhood area }\end{array}$} & \multicolumn{4}{|c|}{ Contribution ratio } \\
\hline S. N. & $\begin{array}{l}\text { Proposed land } \\
\text { use }\end{array}$ & $\%$ & Rop. & Plots along & $\begin{array}{l}\text { General } \\
\text { plot (\%) }\end{array}$ & $\begin{array}{c}\text { Corner } \\
\text { plot (\%) }\end{array}$ & $\begin{array}{c}\text { Open space } \\
(\%)\end{array}$ \\
\hline 1 & $\begin{array}{l}\text { Outer Ring } \\
\text { Road }\end{array}$ & 11.0 & 188 & $\begin{array}{l}\text { Outer Ring } \\
\text { Road }\end{array}$ & 41.0 & 46.0 & \\
\hline 2 & Internal roads & 15.6 & 265 & $\begin{array}{l}\text { 11m wide } \\
\text { road }\end{array}$ & 36.0 & 41.0 & \\
\hline 3 & Open space & 2.9 & 49 & $\begin{array}{l}8 \mathrm{~m} \text { wide } \\
\text { road }\end{array}$ & 31.0 & 36.0 & \\
\hline 4 & $\begin{array}{l}\text { Residential } \\
\text { area }\end{array}$ & 70.5 & 1,196 & $\begin{array}{l}6 \mathrm{~m} \text { wide } \\
\text { road }\end{array}$ & 26.0 & 31.0 & \\
\hline 4.1 & $\begin{array}{l}\text { Plots to be } \\
\text { returned }\end{array}$ & 63.9 & 1,084 & $\begin{array}{l}\text { Open } \\
\text { space }\end{array}$ & & & 32.0 \\
\hline 4.2 & Plots to be sold & 6.6 & 112 & Note: 1 Rop & $=508$ sq. m., & & \\
\hline Total & & 100 & 1,698 & Source: (WI & LINK Consul & ants, 2005) & \\
\hline
\end{tabular}

Allocation of singular land use of housing without socio-cultural functions combined with construction of individual buildings without coordination with the surrounding structures will definitely reduce the opportunity for interaction and socialisation among the residents in these planned areas too thereby not only minimising the mutual assistance but also deteriorating the sense of place and community (Shrestha, 2007). Lack of urban design approach and involvement of architects or planners only instead of urban designers will significantly limit the integration of two dimensional layout into three dimensional built form. As the individual building construction on the private land is regulated by the existing building bylaws, the quality of 'public realm' will be difficult to achieve. 
Since the newly developed sites through land pooling will not be self-sufficient in terms of mixed land use and infrastructure provisions such as water supply, electricity, telephone line and so on, the extra population living in these areas will have to commute to the existing urban centres for work and have to rely on the existing facilities and amenities. Population growth will definitely create extra demand for urban services and infrastructure facilities. Failure to supply in the same proportion will make them costly, insufficient and unreliable and highly vulnerable. The extra trip generated by people living in newly developed areas will create more traffic congestion particularly in the existing city centres and historical core areas thereby increasing air and noise pollution as well as commuting time with negative consequences on health, psychology, socialisation and economy.

Environmental pollution is responsible for various diseases such as dysentery and typhoid, high infant mortality, up to 101 per 1000 live births and various acute respiratory infectious diseases. Reduction of $\mathrm{PM}_{2.5}{ }^{6}$ level in Kathmandu valley by half (by $47.4 \mu \mathrm{g} / \mathrm{m}^{3}$ ), will reduce daily mortality by 7 percent and hospital admissions by 24 percent whereas reduction of $\mathrm{PM}_{2.5}$ level in Kathmandu municipality by half (by $63.4 \mu \mathrm{g} / \mathrm{m}^{3}$ ), will reduce mortality by approximately 10 percent and hospital admissions by 32 percent (Clean Energy Nepal \& Environment \& Public Health Organisation, 2003). The cost of morbidity resulting from $\mathrm{PM}_{10}$ was found to be NRs.180 million and total health damage to be NRs.210 million (World Bank, 1997). It is estimated that NRs.0.5 billion per year in tourism revenue is lost due to air pollution in Kathmandu valley (ibid). In terms of water supply, though the daily demand is of 170 mld (million litres per day) in the valley, the Nepal Water Supply Corporation is able to supply only 120 mld during the rainy season and just 80 mld during dry season (NWSC, 2004). Intensive use of ground water for water supply has reduced the groundwater level from $9 \mathrm{~m}$ to as low as $68 \mathrm{~m}$ over the last few years thereby drying off the traditional dug wells and stone spouts (Dhungedhara). Addition of population in the already congested urban centres and the historical core will not only expose significant percentage of population under the seismic risk but also make rescue and relief operation difficult in case of a big earthquake.

Fifth, numerous radial roads (2-4 lanes) merging into the proposed ORR (8 lanes in total) will form 'bottle neck' at the road junctions. Smooth vehicular movement will be difficult unless the junctions are redesigned. Significant amount of extra budget will be required to improve those junctions which can be neither fulfilled from the land pooling mechanism nor from the internal source of the government. Sixth, numerous historical towns like Changunarayan (World Heritage Site), Bungamati and Khokana (potential to be included in the World Heritage Site) have preserved their cultural and religious significance up to now due to little influence from the haphazard urban

\footnotetext{
${ }^{6}$ Particulate Matter (PM) is a mixture of extremely small particles and liquid droplets found in the air. Sources of particulate pollution include woodstoves, fires, wind-blown dust, automobiles, and industry. $\mathrm{PM}_{10}$ refers to particulate matter 10 microns in diameter and smaller whereas $\mathrm{PM}_{2.5}$ refers to particulate matter 2.5 microns in diameter and smaller. The average strand of human hair is 70 microns in diameter.
} 
growth. Linking these traditional settlements with the ORR and rapid urban development along both sides of the road will increase the vulnerability of losing their cultural identity. Last, people are not adequately informed regarding feasibility study of this project from multi-disciplinary perspective. The government has hired different consulting firms for the feasibility and detail work of various segments of the road.

\section{Pre-requisites for implementation of ORR}

Planned development enhances economic growth, allows optimum use of resources, and reduces disaster vulnerability. The ORR project acting as a planning tool can guide the future development of the valley. It has a lot of potential not only to fulfil the housing deficit, shortage of qualitative infrastructure and other public amenities required for the citizens but also to address the issues of urban poor, slums and squatter settlements. In fact, the vision of the Kathmandu valley to develop it as a National Capital can be realised. To achieve all these, there are some pre-requisite conditions to be addressed.

First, this mega project comprising of transportation and land development sectors require a strong and powerful implementing body that not only coordinates various central, valley and local levels agencies but also develops framework for the implementation of the project. The proposed site shall be designated as 'comprehensive development zone' taking extra lands beyond the $250 \mathrm{~m}$ on both sides of ORR. The planning standards and urban design guidelines along with land use and density zoning shall be formulated for neighbourhood planning, infrastructure development and road construction in such zone. Moreover, both the central and local governments together with the public utility providing agencies need to participate in this project for the planned development as well as for sharing development costs.

Second, the present technique of land pooling needs to be modified in many ways especially in terms of master layout plan, land use distribution and in financing the projects. Layout plan shall be prepared through urban design approach. The proposed satellite towns shall be designed for 'high rise-high density' at the nodal points with planning of 'low rise-high density' mixed housing and other community activities at the peripheral areas. Some of the public facilities required for the cities such as central bus terminals, administrative centre, sport complex and entertainment zone shall be fixed, taking the valley as a whole in context. All these activities will reduce the population density and pressure on infrastructure in the existing city centre and historic core areas. In this way, the issues of housing urban poor, higher density through mixed housing types (including apartment) and other social and emergency amenities can be incorporated in the residential neighbourhoods and commercial centres.

Third, the implementing agency shall develop urban design policies of providing tax incentives, floor area bonus and other benefits for private sector to encourage shifting of business activities from the existing urban centres to the newly planned areas as well as for mix used 
development. Also, the present proposed mechanism of formulating 'Land Management SubCommittees' in each three districts under the existing Town Development Act 1988 is inadequate. Instead, a central level coordination mechanism should be developed to coordinate many municipalities, village development committees and city level line agencies. The present chaotic condition of traffic situation of the valley shall be regulated through multiple measures: regulating land use and transportation network, encouraging use of public vehicles but discouraging private one especially two wheelers, improving street network and road junctions, defining continuous pedestrian movement network, improving traffic management system, and so on.

Fourth, conservation oriented development plan and programme for traditional settlements like Changunarayan, Bungamati and Khokana is essential so that the benefits of road construction could be realised in economic development without destructing the historical monuments. Promotion of cultural heritage and its marketing will not only benefit the locals but also the conservation of the town. Enhancement of local crafts and arts, building materials including intangible heritage is also recommended.

\section{Conclusions}

Though this ambitious project posses both challenges as well as opportunities for the systematic growth of the Kathmandu valley. Reviewing the public sector's performance in urban development and infrastructure projects in the past, present political instability in the country, people's huge expectation from this development, such complex and national level project needs more public discussion and critical analysis on different aspects of urban development and public life. As the existing legal and institutional framework is simply inadequate and ineffective, implementation of ORR project in the present form will create new set of urban problems thereby making the situation of the valley worse. It will attract more population from the surrounding districts and promote 'low rise low density' individual houses with many vacant developed plots in the land pooled areas but urban sprawl in the further extended areas (dormitory pockets). Most of the people living in these areas will be not only working in the existing urban centres of the Kathmandu valley but they will also share the existing facilities and social and emergency amenities. To avoid such situation and to get the benefits of the ORR project, changes in the present practice of land pooling system and improvement in the existing legal and institutional framework is essential. Then only, development of nodal points as a 'self sufficient' business centres equipped with high tech infrastructure, required for the $21^{\text {st }}$ century is possible to achieve balance growth of the valley and to reduce development pressure in the historical core areas. 
Implementing the proposed outer ring road in Kathmandu Valley

\section{References}

Adhikari, J. \& Bohle, H. G (1999). Urbanization, government policies and growing food insecurity in Kathmandu Metropolis. Studies in Nepali History and Society, 4 (1): 191-246.

Basnet, P. (2011). An analysis of urbanization trend, pattern and policies in Nepal, SONSIK Journal, 3: 64-71.

Central Bureau of Statistics Nepal [CBS]. (1997). Nepal living standards survey report, Volume I and II. Kathmandu: CBS.

. (2012). National population and housing census - 2011. Retrieved 15 February 2013 from http://census.gov.np/.

Clean Energy Nepal (CEN) \& Environment and Public Health Organisation (ENPHO). (2003). Health impacts of Kathmandu's air pollution. Kathmandu: Kathmandu Electric Vehicle Alliance.

Choe, K. \& Pradhan, P. (2010). Unleashing economic growth, region-based urban development strategy for Nepal. Manila: Asian Development Bank.

Department of Urban Development and Building Construction (DUDBC). (2008). Outer Ring Road Development Project: An Introduction. Kathmandu: Ministry of Physical Planning and Works.

Ertur, O. (1994). The need for a national urbanization policy in Nepal. Asia Pacific Population Journal. 9(3):19-36.

Ghimire, H. (2008). An assessment of the environmental problems in the Kathmandu valley of Nepal. An unpublished dissertation. Miami: Miami University.

Halcrow Fox Associates et al. (1991). Kathmandu Valley urban development plans and programmes: Strategy plan for Kathmandu Valley. Kathmandu: Department of Housing and Urban Development.

Japan International Cooperation Agency (JICA). (1993). The study of Kathmandu Valley urban road development. Kathmandu: Government of Nepal.

Kathmandu Valley Town Development Committee (KVTDC). (2000). Development plan of Kathmandu valley - 2000. Kathmandu: Ministry of Physical Planning and Works.

Manandhar, M. K. (2008). Detail planning report on land pooling for Chovar - Satungal sub-area. Kathmandu: Fulbright Consultancy Private Limited.

Maneesh, G. P. (2003). Urban open spaces in Kathmandu: Problems and prospects. Vaastu: An Annual Journal of Architecture: 5:45-46.

Maskey, K. (2007). Analyzing the role of the existing land and building regulations on the affordability of housing for urban poor: A case of riverbank area of Kathmandu. Rotterdam: Institute of Housing and Urban Development Studies.

Ministry of Law and Justice (MoLJ). (1992). Traffic and Transport Management Act 1992. Kathmandu: Law Books Management Board. 
Implementing the proposed outer ring road in Kathmandu Valley

(1999). Local Self-Governance Act 1999 (2055). Kathmandu: Law Books Management

Board.

Ministry of Population and Environment (MoPE). (1999). Environmental planning and management of the Kathmandu Valley. Kathmandu: MoPE.

Muzzini, E. \& Aparicio, G. (2013). Urban Growth and Spatial Transition in Nepal: An Initial Assessment. Washington D.C: World Bank.

Nepal Development Forum (NDF). (2002). Medium term expenditure framework (2002/3-2004/5). Kathmandu: Urban Development, Housing and Building Sector, Government of Nepal.

Nepal Water Supply Corporation (NWSC). (2004). Annual report 2004. Kathmandu: NWSC.

Pant, A.D. (2005). The outer ring road - A planning tool?. SCITECH Nepal: A Journal of Scientific and Technical Studies. 9(1):13-16.

Sakai, T., Gajurel, A.P., Tabata, H. \& Upreti, B. N. (2001). Small -amplitude lake level fluctuations recorded in aggrading deltaic deposits of the Upper Pleistocene Thimi and Gokarna formations, Kathmandu Valley, Nepal. Nepal Journal of Geological Society, 25 (special issue): 43-51.

Shrestha, B. K. (2006a). Land pooling system in the Kathmandu Valley - successful in financing infrastructure but failure in achieving urban environment. SCITECH Nepal: A Journal of Scientific and Technical Studies. 9 (3):7-19.

. (2006b). Overhead pedestrian bridges on the streets of Kathmandu: Successful story OR failure model?' Spaces: Art-Architecture - Design: 2(6):60-64.

. (2007). Planned residential neighbourhood development in Kathmandu Valley: Community building or provision of physical infrastructure?' Protibesh: Environment, Journal of the Department of Architecture, 11(1):33-44.

Shrestha, B. K. (2010). Housing provision in the Kathmandu Valley: Public agency and private sector initiation, Urbani izziv, 21 (2): 85-95.

. (2005). How not to design a neighbourhood - Reviewing different residential precincts of Kathmandu. SCITECH Nepal: A Journal of Scientific and Technical Studies, 8(2): 46-69.

. (2013).Squatter Settlements in the Kathmandu Valley: Looking Through the Prism of Land Rights and Tenure Security, Urban Forum. 24 (1): 119-135.

Shrestha, B. K. \& Shrestha, S. (2006). Privatisation of public Spaces: Transformation of Dharahara - Sundhara Square. Spaces: Art - Architecture - Design. 2 (5): 60-64.

Shrestha J. A. (2007). Role of building bylaws and regulations in shaping urban forms: A case of Kathmandu. An unpublished dissertation. Hong Kong; University of Hong Kong.

WELINK Consultants (P) Ltd. (2005). Preparation of model land readjustment plan. Kathmandu: Department of Urban Development and Building Construction.

World Bank. (1997). URBAIR Urban air quality management strategy in Asia: Kathmandu Valley report. New York: World Bank. 